Edukids volume 17 (1) tahun 2020

EDUKIDS: Jurnal Pertumbuhan, Perkembangan, dan Pendidikan Anak Usia Dini

Jln. Dr. Setiabudhi No. 229 Kota Bandung 40154. e-mail: edukid@upi.edu website: http://ejournal.upi.edu/index.php/edukid

\title{
PENERAPAN LAYANAN KESEHATAN DAN GIZI DALAM PENYELENGGARAAN PAUD HOLISTIK INTEGRATIF DI TK ALAM PELOPOR RANCAEKEK
}

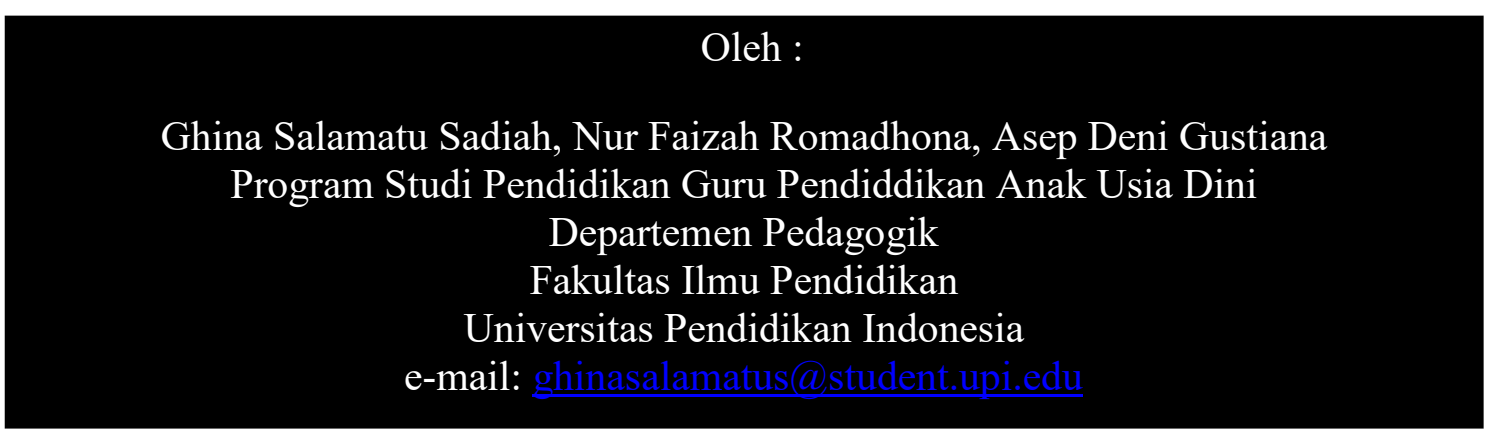

\begin{abstract}
Abstrak: Penelitian ini dilatar belakangi oleh situasi dilapangan, dimana layanan kesehatan dan gizi dalam penyelenggaraan Paud Holistik Integratif ini masih jarang diterapkan di setiap lembaga pendidikan anak usia dini, sehingga kebutuhan esensial anak khususnya dalam aspek kesehatan dan gizi belum terpenuhi secara optimal. Tujuan penelitian ini untuk mengetahui penerapan layanan kesehatan dan gizi dalam penyelenggaraan Paud Holistik Integratif di TK Alam Pelopor Rancaekek. Penelitian ini menggunakan pendekatan kualitatif dengan desain penelitian studi kasus. Teknik pengumpulan data menggunakan, wawancara dan studi dokumentasi, dengan narasumber dari kepala sekolah, dua guru dan satu orangtua murid. Analisis data menggunakan analisis data tematik. Hasil Penelitian menunjukan : pertama perencanaaan pelaksanaan layanan kesehatan dan gizi di TK Alam Pelopor Rancaekek dimulai dengan membuat pedoman pelaksanaan program layanan Holistik Integratif yang didalamnya mencangkup pelaksanaan layanan kesehatan dan gizi, rangsangan pendidikan, pembinaan moralemosional, pengasuhan dan keamanan. Kedua, pelaksanaan layanan kesehatan dan gizi di TK Alam Pelopor dilaksanakan dengan menyesuaikan dana operasional yang ada di sekolah. Bentuk layanannya terdiri dari pemeriksaan kesehatan secara rutin oleh petugas kesehatan setempat maupun oleh gurunya sendiri, pemberian makanan tambahan bagi peserta didik, dan pembiasaan hidup sehat di kalangan peserta didik. Melalui pemberian layanan tersebut dapat meminimalisir permasalahan kesehatan dan gizi yang biasa terjadi pada anak, sehingga tingkat kesakitan anak dapat berkurang. Ketiga, evaluasi layanan kesehatan dan gizi yang telah dilaksanakan di TK Alam Pelopor Rancaekek dilakukan berdasarkan indikator pencapaian yang telah dibuat dari pedoman pelaksanaan program Holistik Integratif.
\end{abstract}

\section{Kata kunci: layanan kesehatan dan gizi, penerapan PAUD holistik integratif}

Abstract: This research is motivated by the situation in the field, where health and nutrition services in the implementation of Integrative Holistic Paud are still rarely applied in every early childhood education institution, so that the essential needs of children, especially in aspects of health and nutrition have not been optimally fulfilled. The purpose of this study was to determine the application of health and nutrition services in the implementation of Integrative Holistic Paud at TK Pelopor Rancaekek. This research uses a qualitative approach with a case study research design. Data collection techniques using, interviews and documentation study, with speakers from the 
principal, two teachers and one parent of students. Data analysis uses thematic data analysis. The results of the study show: first the planning of the implementation of health and nutrition services in Alam Pelopor Rancaekek Kindergarten begins by making guidelines for the implementation of the Integrative Holistic service program which includes health and nutrition service implementation, education stimulation, moralemotional development, care and security. Second, the implementation of health and nutrition services at Alam Pelopor Kindergarten is carried out by adjusting the operational funds available at the school. The form of service consists of routine health checks by local health workers and by the teacher himself, providing additional food for students, and the habit of healthy living among students. Through the provision of these services can minimize health and nutrition problems that commonly occur in children, so that the level of child pain can be reduced. Third, evaluation of health and nutrition services that have been carried out at Alam Pelopor Rancaekek Kindergarten are based on achievement indicators that have been made from the guidelines for the implementation of the Integrative Holistic program.

\section{Keywords: health and nutrition services, application of holistic integratif PAUD}

\section{PENDAHULUAN}

Anak Usia Dini (AUD) adalah anak yang berumur 0-59 bulan, pada masa ini anak akan mengalami pertumbuhan dan perkembangan yang cukup pesat, selain itu anak pula akan sangat rentan terkena permasalahan kesehatan dan kekurangan gizi yang dapat menjadi hambatan dalam proses pertumbuhan dan perkembangannya (Ariani, 2017). Hambatan dalam proses pertumbuhan dan perkembangan anak tersebut dapat dicegah dengan asupan gizi yang baik yang dapat menunjang kesehatan dari anak tersebut. Anak memerlukan makanan dengan kuantitas dan kualitas yang lebih baik dibandingkan dengan orang dewasa, karena hal tersebut merupakan fondasi untuk kesehatan jangka panjang, juga kekuatan dan kemampuan intelektualnnya (Davidson, dkk, 2017).

Layanan kesehatan dan gizi juga sangat penting diberikan pada anak, karena hal ini dapat dijadikan sebagai sarana pendukung agar meminimalisir permasalahan yang dapat terjadi pada anak tersebut. Untuk meminimalisir permasalahan tersebut dibutuhkan layanan khusus agar anak dapat mencapai kesehatan dan kebutuhan gizi yang optimal. Peryataan ini dapat dipertegas melalui pendapat dari Astuti (2016), yang mengatakan bahwa terdapat tiga pilar layanan agar tumbuh kembang anak dapat terbentuk secara optimal, yaitu dengan adanya layanan kesehatan, asupan gizi dan stimulasi psikososial.

Menurut Prima, dkk (2017) perilaku kesehatan yang dapat diberikan kepada anak dapat di klasifikasikan menjadi tiga bagian yaitu, memberikan perilaku pemeliharaan kesehatan (health maintanance) yang terdiri dari, perilaku pencegahan penyakit, perlilaku penyembuhan penyakit bilamana sakit, serta perilaku pemulihan kesehatan bilamana telah sembuh dari penyakit, perilaku peningkatan kesehatan, apabila seseorang dalam keadaan sehat, perilaku memberikan makanan dan minuman yang sehat, yang kedua perilaku pencarian dan penggunaan fasilitas pelayanan kesehatan atau sering disebut perilaku pencarian pengobatan (health seeking behaviour). Dan terakhir yaitu perilaku yang menyangkut upaya atau tindakan seseorang pada saat menderita penyakit dan atau kecelakaan. Tindakan atau perilaku ini dimulai dari mengobati sendiri (self treatment) sampai mencari pengobatan diluar. Tindakan atau perilaku ini perlu diterapkan sebagai layanan kesehatan untuk anak agar anak memiliki kesehatan yang baik dikemudian hari. Apabila layanan kesehatan tidak diberikan pada anak maka akan berpengaruh 
terhadap permasalahan kesehatan anak tersebut. hal-hal yang sering muncul ialah anak akan sangat rentan terkena penyakit seperti seperti batuk/pilek, flek atau TBC, diare, demam, campak, infeksi telinga, dan penyakit kulit (Astuti, 2016, hlm 265).

Layanan PAUD yang sistematis dan terencana sangat diperlukan dalam mewujudkan suatu lembaga PAUD yang berkualitas. Dengan adanya lembaga PAUD yang berkualitas maka kebutuhan esensial anak akan terpenuhi secara utuh. kebutuhan tersebut perlu terpenuhi secara utuh agar perkembangan anak tersebut dapat terbentuk dengan baik sejak dini. Menurut Salim (dalam Yuniarto, 2014, hlm. 4) "masa usia dini merupakan masa pembentukan dasar-dasar kepribadian seseorang yang kelak menjadi karakter di masa dewasanya". Untuk itu, masa usia dini perlu dimanfaatkan secara optimal agar pembentukan karakter anak dapat terbentuk sejak dini, karena hal tersebut menjadikan titik awal yang menentukan masa depan anak tersebut.

Pentingnya layanan PAUD tersebut sangat diperlukan agar anak sedini mungkin dapat terfasilitasi dalam mengoptimalkan tumbuh kembangnya sesuai dengan potensi yang dimiliki. Dalam rangka memfasilitasi kebutuhan anak tersebut, pemerintah mengeluarkan kebijakan yang mensyaratkan bahwa penyelenggaraan Pendidikan Anak Usia Dini (PAUD) harus dilakukan secara Holistik Integratif (HI). PAUD HI ini dimaksudkan sebagai upaya pengembangan anak usia dini yang dilakukan untuk memenuhi seluruh kebutuhan esensial anak yang beragam dan saling terkait secara simultan, sistematis, dan terintegrasi. Kebijakan tersebut tercantum dalam Peraturan Presiden No. 60 Tahun 2013 yang tidak hanya melayani aspek pendidikan semata namun aspek lainnya juga seperti, kesehatan, gizi, perawatan, pengasuhan, serta perlindungan dan kesejahteraan anak (Juknis PAUD HI, 2015, hlm. 4).

Berdasarkan permasalahan diatas diperlukan pengkajian ulang mengenai kebijakan layanan PAUD HI tersebut khususnya di bidang layanan kesehatan dan gizi karena masih banyak terdapat kasus anak yang belum mendapatkan layanan kesehatan dan gizi dengan baik. Hal ini menunjukan bahwa layanan kesehatan dan gizi yang baik ini sangat penting diberikan kepada anak karena dapat dimanfaatkan sebagai pencegahan terhadap hal-hal yang dapat mengganggu kesehatan anak.

Dalam Penelitian yang ditulis Wijaya (2010), program layanan PAUD yang efektif telah berkembang pesat selama 10 tahun terakhir ini, sehingga upaya program PAUD yang terintegrasi yaitu layanan PAUD HI ini dijadkan sebagai upaya program yang dapat mensejahterakan Anak usia dini. Namun karena program ini masih berjalan masing-masing di setiap sektornya mengakibatkan program layanan PAUD $\mathrm{HI}$ ini belum berjalan sebagaimana mestinya. Penelitian yang ditulis Alfiana (2016) mengatakan hal serupa, sebagian besar Lembaga PAUD yang ada di Indonesia sudah melakukan pelayanan tetapi belum terintegrasi, sehingga masih banyak anak usia dini yang belum terlayani secara maksimal. Oleh sebab itu, diperlukan adanya layanan pendidikan anak usia dini yang menyelenggarakan program lebih dari satu bentuk layanan PAUD sebagai PAUD Terpadu yang sesuai dengan kebijakan layanan PAUD Holistik Integratif.

Adapun dalam penelitian ini peneliti menemukan pelaksanaan PAUD holistik integratif dalam penyelenggaraan layanan kesehatan dan gizi yang ada di TK Alam Pelopor Rancaekek. TK Alam Pelopor Rancaekek merupakan salah satu lembaga pendidikan anak usia dini yang telah menerapkan layanan PAUD Holistik Integratif. Sejak awal berdiri TK Alam 
Pelopor Rancaekek tahun 2000, layanan kesehatan dan gizi sudah menjadi perhatian lebih dimana tujuan dibangunnya TK ini yaitu membangun keterampilah hidup (life-skill) peserta didik sehingga menjadi anak yang sehat dan membangun pengetahuan keilmuan pada peserta didik, sehingga ia menyadari, memahami dan menguasai ilmu pengetahuan secara holistik.

Berdasarkan latar belakang permasalahan diatas, maka berikut ini dirumuskan beberapa pertanyaan penelitiannya:

1. Bagaimana perencanaan layanan kesehatan dan gizi dalam penyelenggaraan PAUD HI di TK Alam Pelopor Rancaekek?

2. Bagaimana penyelenggaraan layanan kesehatan dan gizi dalam penyelenggaraan PAUD HI di TK Alam Pelopor Rancaekek?

\section{METODE}

Metode dalam penelitian ini adalah metode Studi kasus dengan pendekatan kualitatif. Alasan peneliti memilih metode dengan pendekatan tersebut dikarenakan sangat cocok dengan fokus masalah yang peneliti ambil yaitu Penerapan layanan kesehatan dan gizi dalam penyelenggaraan PAUD holistik Integratif. Menurut Schramm, 1971 (dalam Yin, 2003) Metode penelitian studi kasus ini merupakan suatu metode mengenai suatu kasus yang sering dijumpai yang hanya mengulangi jenis-jenis topi dari masalah yang sudah di tetapkan terlebih dahulu. Inti dari studi kasus ini yaitu dengan melihat kecenderungan utama diantara semua jenis kasus yang ada di lapangan, dengan melihat beberapa aspek pertanyaan agar mendapatkan seraikaian keputusan seperti, mengapa permasalahan tersebut diambil, bagaimana diterapkannya, dan hasil apa yang di dapatkan dari permasalahan tersebut.
3. Bagaimana evaluasi penyelengaraan layanan kesehatan dan gizi dalam penyelenggaraan PAUD HI di TK Alam Pelopor Rancaekek ?

Penelitian yang dilakukan tentunya memiliki tujuan. yang ingin dicapai yaitu sebagai berikut:

1. Untuk mengetahui perencanaan layanan kesehatan dan gizi dalam penyelenggaraan PAUD HI di TK Alam Pelopor Rancaekek.

2. Untuk mengetahui penyelengaraan layanan kesehatan dan gizi dalam penyelenggaraan PAUD HI di TK Alam Pelopor Rancaekek.

Untuk mengetahui bagaimana evaluasi dari proses penyelenggaraan layanan kesehatan dan gizi dalam penyelenggaraan PAUD HI di TK Alam Pelopor Rancaekek.

Subyek dalam penelitian ini terdiri dari informen dan responden, informen terdiri dari kepala sekolah, satu guru kelas A dan satu gutu kelas B. Sedangkan responden terdiri dari satu orang tua peserta didik.

Lokasi penelitian penyelenggaraan program layanan kesehatan dan gizi ini akan dilaksanakan di TK Alam Pelopor Rancaekek dengan lama penelitian selama satu bulan.

Instumen dalam penelitian ini berpedoman pada juknis PAUD Holistik Integratif 2015.

Prosedur analisis data dalam penelitian ini menggunakan teknis analisis data tematik, Menurut Braun dan Crakle (2006) terdapat beberapa langkah analisis data tematik yaitu; Mengenal baik data, menentukan kode awal atau meng-coding, menentukan tema, meninjau ulang tema, mendefinisikan dan memberi nama tema, dan membuat laporan penelitian yang terdapat di bab IV yang di mulai dari tahap perencanaan, Tahap pelaksanaan dilapangan, Tahap membuat laporan penelitian, 
Teknik pengumpulan data dalam penelitian ini yaitu terdiri dari:

1. Wawancara

Wawancara merupakan alat rechecking atau pembuktian terhadap informasi atau keterangan yang diperoleh sebelumnya. Teknik wawancara yang digunakan dalam penelitian kualitatif adalah wawancara mendalam. Wawancara mendalam (in-depth interview) adalah proses memperoleh keterangan untuk tujuan penelitian dengan cara tanya jawab sambil bertatap muka antara pewawancara dengan informan atau orang yang diwawancarai, dengan atau tanpa menggunakan pedoman (guide) wawancara, di mana pewawancara dan informan terlibat dalam kehidupan sosial yang relatif lama (Moleong, 2010: 186).

1. Studi Dokumentasi

Di samping menggunakan teknik wawancara, maka penelitian ini juga menggunakan teknik dokumentasi. Dokumentasi ini untuk mengabadikan peristiwa-peristiwa tertentu yang relevan dengan pokok permasalahan yang diteliti yang dianggap penting dan mendukung dengan berupa foto, mengkaji dokumen yang sudah ada, ataupun mengkopi dokumen tersebut guna mengkaji lebih dalam. Dalam penelitian ini dokumentasi di lakukan agar peneliti dapat memperoleh informasi secara maksimal, yang dapat menggambarkan kondisi subjek atau objek yang diteliti dengan benar. Dokumentasi merupakan sumber data yang stabil, menunjukkan suatu fakta/bukti bahwa peneliti yang telah melakukan penelitian. Dan dokumen pendukung dalam penelitian ini berupa:

1) Program semester (Prosem)
2) Rancangan perencanaan pembelajaran harian (RPPM)

3) Rancangan perencanaan pembelajaran harian (RPPH)

4) Laporan pelaksanaan program holistik integratif TK Alam Pelopor Rancaekek

5) Laporan program parenting $\mathrm{TK}$ Alam Pelopor Rancaekek

6) Laporan bentuk keterlibatan orang tua pada satuan paud TK Alam Pelopor Rancaekek

7) Dokumentasi berupa kegiatan mengenai layanan kesehatan dan gizi di TK Alam Pelopor Rancaekek.

\section{HASIL DAN PEMBAHASAN}

\section{Perencanaan}

Perencanaan program layanan kesehatan dan gizi dalam penyelenggaraan PAUD Holistik Integratif di TK Alam Pelopor Rancaekek ini merupakan langkah terpenting dalam pelaksanaan layanan kesehatan dan gizi selama satu semester di sekolah ini. Perencanaan layanan kesehatan dan gizi di TK Alam Pelopor Rancaekek dirancang dengan membuat pedoman yang berisi tentang pelaksanaan program Holistik Integratif dan layanan kesehatan dan gizi ini termasuk didalamnya. Tujuan pedoman ini dibuat untuk dijadikan sebagai bahan acuan bagi pendidik dan pengelola Paud serta orang tua/ wali peserta didik dalam merencanakan, melaksanakan dan mengevaluasi kegiatan Holistik-Integratif di TK Alam Pelopor Rancaekek.

Adapun langkah-langkah perencanaan program layanan kesehatan dan gizi dalam penyelenggaraan PAUD Holistik Integratif di TK Alam Pelopor Rancaekek yang dilakukan oleh pihak sekolah di rancang dalam sebuah laporan pedoman seperti:

1. Merancang bentuk kegiatan

Bentuk kegiatan dalam pelaksanaan program layanan kesehatan dan gizi 
di TK Alam Pelopor Rancaekek ini mengacu pada pelaksanaan layanan PAUD Holistik Integratif yang didalamnya mencangkup pemeriksaan kesehatan secara rutin oleh petugas kesehatan setempat, pemberian makanan tambahan bagi peserta didik, pembiasaan hidup sehat dikalangan peserta didik, pembiasaan kerjasama dan saling tolong menolong di antara sesama peserta didik, dan perlindungan bagi peserta didik dalam lingkungan satuan pendidikan.

2. Menentukan pelaksanaan waktu

Program kegiatan layanan Holistik Integratif dilaksanakan sesuai dengan jadwal yang telah ditetapkan bersama antara pengelola, pendidik, orang tua/wali peserta didik, dan instansi/lembaga terkait program kegiatan Holistik Integratif dalam kalender pendidikan dan program semester dan tahunan.

3. Menentukan pelaksana kegiatan Program kegiatan holistik integratif

PAUD di TK Alam Pelopor

Rancaekek dilaksanakan oleh pengelola PAUD atau pengelola bersama dengan unsur pendidik atau unsur terkait program layanan tersebut.

4. Menyiapkan sarana dan prasarana

Sarana dan prasarana untuk melaksanakan program kegiatan layanan PAUD Holistik Integratif di TK Alam Pelopor Rancaekek ini menggunakan fasilitas yang ada di lembaga PAUD dan bekerja sama dengan instansi terkait yang telah diajak kerjasama dalam pelaksanaan program tersebut.

Perencanaan Layanan kesehatan gizi dalam penyelenggaraan PAUD Holistik Integratif ini sangat penting di lakukan agar segala sesuatu kegiatan mengenai layanan kesehatan dan gizi untuk anak usia dini dapat berjalan dengan baik dan gterintegrasi.
Perencanan pelaksanaan progam layanan kesehatan dan gizi dalan suatu lembaga PAUD perlu di persiapkan dengan baik dan terencana agar program-program yang telah dibuat dapat terlaksana sesuai harapan dan dapat membantu peningkatan kebutuhuhan kesehatan dan gizi pada anak di sekolah dapat terlaksana. Perencanaan layanan kesehatan dan gizi penting diterapkan dalam setiap lembaga PAUD agar kebutuhan anak khususnya dalam aspek kesehatan dan gizi bisa didapatkan anak supaya tumbuh kembang anak dapat berjalan secara optimal, sejalan dengan tujuan penerapan PAUD Holistik Integratif dalam Bappenas (2012), bahwa Tujuan utama diterapkan program PAUD Holistik Integratf yaitu mengacu kepada kebutuhan esensial anak usia dini agar dapat terpenuhi, sehingga anak dapat berkembang sebagai mana mestinya secara optimal sesuai dengan tahap perkembangan dan usianya. Kebutuhan essensial anak tersebut mencangkup beberapa aspek fisik, non fisik seperti mental, emosional, dan sosial. Pelaksanaan penyelenggaraan layanan kesehatan dan gizi di TK Alam Pelopor Rancaekek ini dilaksanakan sesuai dengan kemampuan dari sekolah ini sendiri, pelaksanaan layanan kesehatan dan gizi di TK ini disesuaikan dengan dana yang ada di sekolah. Dalam Perpres Nomor 60 Tahun 2013 menyebutkan bahwa Sasaran program PAUD Holistik Integratif ini ditujukan untuk setiap lembaga Satuan Pendidikan Anak Usia Dini namun dalam pelaksanaanya dapat disesuaikan dengan kemampuan dari setiap lembaga itu sendiri. pernyataan tersebut mengandung arti pelaksanaan kayanan kesehatan dan gizi dalam penyelenggaraan PAUD Holistik Integratif dapat dilaksanakan sesuai dengan kemampuan dari sekolah itu sendiri baik dalam segi sarana maupun prasarananya. Dan di TK Alam Pelopor Rancakek ini telah mengoptimalkan 
pemberian layanan kesehatan dan gizi dengan semaksimal mungkin dan apabila terjadi keterbatasan sarana dan prasarana pihak sekolah pun melakukan kerjasama dengan pihak dari luar sekolah.

Perencanaan pelaksanaan layanan kesehatan dan gizi di TK Alam Pelopor Rancaekek dengan pihak dari luar ini, sekolah bekerjasama dengan lembaga kesehatan seperti Posyandu untuk menjalankan kegiatan yang bersangkutan dengan layanan kesehatan dan gizi. kerja sama antara pihak sekolah dan Posyandu ini dilakukan untuk memfasilitasi anak agar pendapatkan pelayanan dari tenaga medis karena beberapa layanan yang dibuat oleh sekolah tidak bisa sembarangan di berikan kepada selain ahlinya. Bentuk perencanaan program kegiatan layanan kesehatan dan gizi di TK Alam Pelopor Rancaekek yang dilaksanakan dengan pihak luar di buat dalam sebuah laporan perencanaan semua kegiatan selama satu tahun kedepan yang telah di bukukan yang terdiri dari:

1. Usaha Kesehatan Gigi Sekolah (UKGS) melalui pemeriksaan dan penyuluhan kesehatan gigi anak oleh Team UKGS sekolah dibawah pimpinan Dokter Gigi dari puskesmas UPTD Kecamatan Rancaekek pada saat awal tahun ajaran yang disebut sebagai penjaringan kesehatan.

2. Pemberian obat cacing oleh puskesmas UPTD Kecamatan Rancaekek.

3. Pemberian imunisasi oleh Puskesmas UPTD Kecamatan Rancaekek.

Pentingnyakerjasamadengan

tenaga medis dalam pelaksanaan layanan kesehatan dan gizi di lembaga PAUD ini perlu dilakukan agar anak tidak mendapatkan pelayanan yang salah. Hal ini sejalan dengan penelitian Usnawati, dkk (2016) bahwa untuk membentuk layanan PAUD terpadu dengan pendekatan Holistik Integratif diperlukan perpaduan dengan lembaga kesehatan seperti BKB-Posyandu-PAUD, hal ini bertujuan agar pemberian layanan pembinaan PAUD dalam bidang layanan kesehatan dan gizi dapat mencapai target SDIDTK bagi anak balita.

Untuk menjalankan suatu layanan kesehatan dan gizi yang baik maka diperlukan kerjasama dengan pihak-pihak lain. Salah satu perencanaan agar program ini dapat terlaksana dengan baik diperlukan juga kerja sama dengan orang tua murid yang bersekolah di TK Alam Pelopor Rancaekek. Bentuk kerjasama dengan orang tua di tk ini dilakukan dengan cara melibatkan orang tua kedalam kegiatan yang termasuk kedalam bentuk layanan kesehatan dan gizi di sekolah. Perencanaan kegiatan ini biasanya dilakukan dengan mengadakan kegiatan komite sekolah yang diselenggarakan pada bulan kedua setelah anak masuk sekolah, kegiatan ini mencangkup sosialisasi SOP Pembelajaran ataupun kegiatan yang akan berlangsung mengenai program yang akan dilaksanakan selama satu semester.

Perencanan program layanan kesehatan dan gizi dalam penyelenggaraan PAUD Holistik Integratif di TK Alam Pelopor sangat penting di diskusikan dengan orang tua murid karena apabila ada kegiatan yang membutuhkan keterlibatan orang tua dalam pelaksanaan program layanan kesehatan dan gizi ini orang tua sudah tahu sebelumnya. Pelibatan orang tua dalam pelaksanaan segala kegiatan di sekolah pun peting dilakukan agar orang tua mengetahui bagaimana pelaksanaan program yang terjadi mengenai layanan kesehatan dan gizi di TK Alam Pelopor Rancaekek ini. Pernyataan ini dikuatkan dengan pendapat dari Widiastiti (2018) bahwa Keterlibatan orang tua merupakan bagian penting dalam pengembangan PAUD Holistik Integratif. Pasalnya, sasaran dalam PAUD Holistik Integratif sebagaimana yang terdapat dalam Peraturan Presiden No 60 Tahun 2013 adalah masyarakat, terutama orang tua 
dan keluarga. Selain itu, orang tua merupakan sosok utama dan pertama dalam mendampingi anak. Sehingga harus terjalin kerjasama antara pihak sekolah dan orang tua untuk mengembangkan PAUD Holistik Integratif. Selain itu Dengan adanya pelibatan orang tua, proses pendidikan anak usia dini dapat berjalan dengan optimal baik saat di sekolah maupun dirumah.

\section{Pelaksanaan}

Pelaksanaan layanan kesehatan dan gizi di TK Alam Pelopr Rancaekek dilaksanakan melalui perencanaan yang telah dibuat dari pihak sekolah dalam pedoman pelaksanaan program Holistik Integratif, yang didalamnya mencangkup pelaksanaan dalam bidang kesehatan dan gizi, rangsangan pendidikan, pembinaan moral-emosional , pengasuhan dan keamanan. Bentuk kegiatan dari layanan kesehatan dan gizi di TK Alam Pelopor Rancaekek berupa pemeriksaan kesehatan secara rutin yang dilakukan oleh pihak sekolah yaitu:

a. Penimbangan Berat Badan Dan Pengukuran Tinggi Badan Yang Dicatat Dalam KMS Secara Berkala Setiap Bulan

Pelaksanaan

penimbangan berat badan dan pengukuran tinggi badan di TK Alam Pelopor Rancaekek dilaksanakan pada awal smester dan akhir smster yang dicatat dalam laporan KMS secara berkala selain itu di TK ini juga melakukan pengukuran lingkar kepala anak yang dilakukan oleh masing-masing guru kelasnya. Kegiatan ini dilaksanakan untuk mengetahui perkembangan anak dalam satu semester ini.

Dalam meningkatkan layanan kesehatan dan gizi di TK Alam Pelopor Rancaekek pihak sekolah melakukan pemeriksaan kesehatan terhadap siswa yang dilaksanakan pada tiap awal semsester. Hal ini penting dilakukan agar pihak sekolah dapat mengetahui bagaimana perkembangan anak didiknya. Dan pemeriksan sederhana yang dapat dilakukan yaitu dengan mengukur tinggi badan, berat badan dan lingkar kepala anak dan dituliskan dalam laporan KMS oleh guru yang bersangkutan. Hal yang sama dikakan oleh Nufus (2016) dalam penelitiannya yang mengatakan bahwa pengecekan kesesehatan tersebut sangat penting dilakukan agar apabila permasalahan maka hal tersebut dapat diminimalisir dan tumbuh kembang anak dapat dimaksimalkan sebagaimana mestinya.

b. Pembiasaan Makan Makanan Sehat Dan Seimbang Atau Pemberian Makanan Tambahan Secara Berkala Selain dari pemeriksaan sederhana seperti kegiatan pengukuran tinggi dan berat badan tersebut di TK Alam Pelopor Rancaekek memberikan layanan pembiasaan makan sehat dan seimbang. Program pembiasaan makan makanan sehat dan seimbang atau pemberian makanan tambahan secara berkala di TK Alam Pelopor Rancaekek ini dilakukan setiap hari senin hingga kamis yang di berikan di waktu makan siang, mengapa di hari jumat tidak dilaksanakan program ini dikarenakan pembelajaran di hari ini hanya sampai jam 10 sehingga program ini tidak bisa dilaksanakan karena jadwal makan siang di sini diadakan pada pukul 11.45 WIB. Berikut jadwal pemeberian jenis makanan yang ada di TK ini:

Tabel 1 Jadwal Makan Siang

Senin: Ayam goreng, sayur asem dan buah semangka

Selasa: Telur, sayur capcay dan buah pepaya

Rabu: Ikan, sayur kangkung dan buah pisang

Kamis: Tempe, sop ayam, dan buah melon

Salah satu program dari layanan kesehatan dan gizi yang ada di TK Alam Pelopor yaitu program pembiasaan 
makanan sehat dan seimbang atau pemberian makanan tambahan dan program ini berikan pada saat makan siang. Pemberian makanan tambahan pada anak dilakukan agar anak terbiasa makan dan minum makanan yang bergizi seimbang seperti, nasi, lauk pauk dan buah. Hal yang sama dikatakan pula oleh Ranti \& Santoso (2004, hlm. 41) kebiasaan makanan dilingkungan tentu saja menjadi kebiasaan makanan bagi anak, pemberian makanan yang sehat bertujuan untuk memperbaiki keadaan gizi pada anak. Untuk itu pemberian makanan sehat dan bergizi ini sangat penting diterapkan kepada anak masa prasekolah. Pelaksanaan program pemberian makanan sehat di TK Alam Pelopor Rancaekek ini telak dilaksanakan dengan cukup baik. Baik dalam segi jenis makanan yang diberikan setiap harinya dengan penentuan jadwal jenis makanan yang harus diberikan kepada anak membuat asupan makanan yang perlu didapatkan oleh anak dapat berjalan dengan maksimal, sehingga asupan gizi anak di sekolah ini dapat diberikan secara optimal. Kegiatan pemberian makanan sehat dengan berbagai macam jenis ini bertujuan agar anak yang tadinya tidak suka makanan seperti sayur menjadi suka dengan sayur karnena dari pihak sekolah sendiri telah membiasakan anak untuk makan sayur sedikit demi sedikit sehingga anak mau makan sayur.

a. Pembiasaan mencuci tangan, menjaga kebersihan diri dan lingkungan

Layanan kesehatan dan gizi yang ada di Tk Alam Pelopor ini yaitu dengan pembiasaan mencuci tangan dan menjaga kebersihan lingkungan. Lingkungan di sekolah ini sudah cukup bersih. Dan salah satu program yang ada disini mengenai menjaga lingkungan yaitu adanya program mengurangi sampah plastik. Pihak sekolah disini membuat aturan bahwa anak tidak boleh membawa makanan yang berbungkus plasti kesekolah dan menggantinya dengan membawa tempat makan yang di bawa sendiri dari rumah. Selain itu di TK Alam Pelopor Rancaekek juga sering melakukan kegiatan bercocok tanam dengan mengajak anak untuk terjun langsung kelapangan dalam menanam.

Bentuk layanan megenai kesehatan dan gizi di Tk Alam pelopor dalam membiasakan anak mengenai bagaimana menjaga kebersihan diri sendiri maupun lingkungan dilakukan secara konsisten setiap harinya dan apabila tema pembelajaran yang ada dalam RPPH yang bersangkutan dengan kesehatan maka guru di sekolah ini melakukan pembelajaran-pembelajaran yang sederhana dan menyangkutpautkannya dengan keadaan lingkungan yang nyata di sekolah. Kegiatan ini penting diberikan kepada anak agar anak paham bagaimana berperilaku bersih dan sehat juga bagaimana menjaga kebersihan diri sendiri maupun lingkungan di sekitarnya. menurut Julianti, dkk (2018) perilaku hidup bersih dan sehat (PBHS) merupakan salah satu upaya preventif(pencegahan terhadap suatu penyakit atau masalah kesehatan dan promotif (peninglatan derajat kesehatan) pada seseorang. Untuk itu sangat penting kegiatan ini diterapkan pada anak usia dini agar anak terbiasa berprilaku dengan hidup bersih.

c. Pengenalan Makan Gizi Seimbang Dengan Melibatkan Orang Tua Dalam Menyiapkan Bekal Untuk Anak Sehari-Hari

Pemberian makanan tambahan di TK Alam Pelopor Rancaekek dilakukan agar kebutuhan makanan anak selain dari makanan pokok perlu juga diberikan makanan tambahan yang sehat agar kebeutuhan gizi anak dapat tercukupi, dengan melibatkan orang tua dalam menyiapkan bekal anak ini bertujuan agar orang tua mengetahui jenis makanan apa yang baik untuk di konsumsi anak sebagai penyeimbang gizinya. Sehingga 
orang tua juga sudah terbiasa menyiapkan makanan sehat di rumah untuk anaknya sehingga anak bukan hanya mendapatkan makanan yang sehat di sekolah tapi anak juga mendapatkannya dirumah juga. Untuk itu keterkibatan orang tua ini sangat penting untuk keberlangsungan program yang ada di sekolah. menurut penelitian Park, Byun \& Kim (2011) menunjukan bahwa keterlibatan oran tua sangat penting dalam keberlangsungan pendidikan anak itu sendiri. Keterlibatan orang tua dalam pendidikan anak juga tercantum dalam Undang-undang No 20 Tahun 2003 Tentang Sistem Pendidikan Nasional, yang menyebutkan orang tua berhak berperan serta dalam memilih satuan pendidikan dan memperoleh informasi tentang perkembangan anaknya. Dapat disimpulkan pelibatan orang tua ini perlu dilakukan agar oran tua tau mengenai perkembangan anak itu sendiri dan kegiatan pelibatan orang tua dalam program pengenalan makanan tambahan di TK Alam Pelopor ini bertujuan agar orang tua mendapatkan sedikit informasi menganai makanan apa yang baik diberikan kepada anak.

d. Memantau Asupan Makanan Yang Dibawa Anak Setiap Harinya Termasuk Jajanan Yang Dikonsumsi Anak Selama Ada Di Satuan PAUD

Layanan Program pemantauan asupan makanan yang diberikan oleh sekolah dilakukan melalui beberapa tahapan agar sekolah dapat mengkontrol asupan makanan apa yang telah dimakan anak, berikut tahapan yang dilakukan:

1) Membuat jadwal jenis makanan yang akan di berikan kepada anak setiap harinya

2) Membuat tata tertib yang berisi tentang kandungan makanan yang tidak boleh dibawa ke sekolah seperti makanan yang mengandung MSG.

3) Pemeriksaan oleh guru kelas masingmasing sebelum anak memakan makanan yang diberikan kepada anak.
Pemantauan asupan makanan yang dilakukan oleh guru terkait di TK Alam Pelopor Rancaekek penting dilakukan agar asupan makanan untuk anak dapat terkontrol dengan baik dan agar anak juga paham untuk tidak jajan makananan yang sembarangan. Dalam penelitan yang dilakukan Polit E, dkk (1993, dalam Triwahyuni, dkk, 2016) pemberian makanan sehat sangat berpengaruh terhadap perkembangan kognitif anak. Sehingga sangat penting dilakukan pemantauan dalam pemberian makanan pada anak agar perkembangan anak tidak terganggu apabila sudah terpantau dengan baik.

e. Penyediaan Alat P3K Untuk Penanganan Pertama Pada Anak Yang Mengalami Luka

Penyediaan alat $\mathrm{P} 3 \mathrm{~K}$ penting diberikan di setiap sekolah sebagai pertolongan pertama apabila terjadi kecelakaan di lingkungan sekolah. khususnya dilembaga PAUD karena anak usia dini sangat rentan terjadi kecelakaan ketika sedang bermain di sekolah untuk itu penyediaan kotak $\mathrm{P} 3 \mathrm{~K}$ ini sangat penting ada di setiap kelas. Namun di TK Alam Pelopor Rancaekek ini belum menyediakan kotak P3K di setiap kelasnya dikarenakan keterbatasan biaya. Dan penyediaan ruang kesehatan di TK Alam Pelopor Rancaekek ini hanya menyediakan satu ruang UKS dan ruangan tersebut bersatu dengan SD yang ada di Sekolah Alam tersebut sehingga jangkauannya cukup jauh dari TK itu sendiri. namun di lingkungan sekolah TK Alam Pelopor ini telah menyediakan berbagai macam tumbuhan pengobatan yang fungsinya untuk pertolongan pertama pada anak apabila ada anak yang sakit ataupun terluka. Sehingga apabila terjadi kecelakaan dapat di obati dengan bahan-bahan alami yang sudah di tanam di lingkungan sekolah.

f. Mengontrol Kondisi Fisik Anak Secara Sederhana (Misalnya Suhu Tubuh, Luka Dsb) 
Bentuk layanan kesehatan dan gizi yang ada di TK Alam Pelopor selanjutnya mengontrol kondisi fisik anak secara sederhana setiap guru di TK ini sering melakukan beberapa pelatihan mengenai cara menangani dan menerka kondisi anak apabila penurunan kondisi fisik pada anak. Sehingga apabila ada anak yang sakit atau terlihat konidisi fisiknya tidak seperti biasanya, guru di TK Alam Pelopor melakukan pengecekan secara sederhana pada anak.

g. Melakukan Deteksi Dini Tumbuh Kembang (DDTK)/ Stimulasi Deteksi Intervensi Dini Tumbuh Kembang (SDIDTK)

Pelaksanaan program deteksi dini tumbuh kembang (DDTK)/ stimulasi deteksi intervensi dini tumbuh kembang (SDIDTK) anak di TK Alam Pelopor Rancaekek ini biasanya dilakukan dengan cara bekerjasama dengan pihak ahli seperti tenaga medis dari puskesmas, sebelumnya pihak sekolah mengubungi pihak puskesmas untuk melakukan ini namun karna keterbatasan dana pihak sekolah melakukan program ini secara mandiri, berikut langkah-langkah kegiatan daru program tersebut:

1. Pelaksanaan program DDTK/SDIDTK dilakukan dengan membuat format formulir yang berisi identitas anak, keluhan utama yang ada pada anak, pemeriksaan rutin mengenai kesehatan anak, dan indikasi permasalahan yang terjadi pada anak.

2. Pemeriksaan dilakukan oleh guru kelas yang ada di TK Alam Pelopor Rancaekek.

3. Bila terjadi indikasi permasalahan atau kasus masalah yang terjadi mengenai tumbuh kembang anak sekolah memberikan surat rujukan agar anak di periksa lebih lanjut kepada tenaga medis yang lebih ahli atau puskesmas daerahnya masingmasing.
4. Selanjutnya sekolah menyerahkan penanganan permaslahan tersebut kepada pihak keluarga dan hanya menerima hasil laporan mengenai permasalahan tersebut dari pihak keluarga yang bersangkutan agar pihak sekolah paham mengenai cara menangani anak ketika terjadi permasalahan tersebut.

Pelaksanaan layanan kesehatan dan gizi dalam upaya pemeriksaan DDTK dan SIDTK di TK Alam Pelopor Rancaekek dilaksanakan oleh pihak sekolah di setiap awal semester. Layanan ini perlu dilakukan agar sekolah dapat mengetahui apakah siswa di TK ini mengalami permasalahan atau tidak. Pernyataan ini dikuatkan dengan adanya Penelitian Fazrin, dkk (2018) yang menyebutkan bahwa upaya pemeriksaan Deteksi Dini Tumbuh Kembang anak penting dilakukan untuk menemukan apakah ada penyimpangan terhadap pertumbuhan dan perkembangan pada anak pra sekolah.

h. Perbaikan Gizi, Seperti Pemberian Vitamin A

Pemberian layanan perbaikan gizi di TK Alam pelopor Rancakek ini dilaksanakan dengan bekerjasama dengan pihak puskesmas. Pelaksanaan layanan tersebut dilakukan dengan cara pemberian vitamin-vitamin untuk anak yang dilakukan sekali dalam satu semester ataupun pemberian makanan sehat atau minuman sehat dari pihak puskesmas, kegiatan ini dilakukan secara menyeluruh kepada anak yang ada di setiap kelas yang ada di TK Alam Pelopor Rancaekek. Program ini dilakukan secara langsung oleh pihak puskesmas itu sendiri namun dibantu oleh guru-guru yang ada di TK ini untuk mengkondisikan anak-anak sebelum program ini diberikan.

Layanan perbaikan gizi dalam bentuk pemberian vitamin sangat penting diberikan kepada anak kondisi anak dapat kembali sebagaimana mestinya. Dari 
hasil wawancara yang sudah saya lakukan di TK Alam Pelopor ini saya tidak menemukan hasil dokumentasi yang dapat mendukung program ini. Pentingnya pemerbaikan gizi dalam bentuk pemberian vitamin A penting diberikan pada anak, karenahal tersebut dapat berpengaruh terhadap kesehatan anak. Penelitian yang dilakukan Murage (2012) menyebutkan pada tahun 2008 anak di negara Kenya yang mengalami kekurangan vitamin A 75\% akan lebih beresiko menderita underweight dibandingkan anak yang diberikan vitamin A. Untuk mencegah hal tersebut maka pemberian vitamin A ini penting untuk anak agar permasalahan mengenai kesehatan tersebut dapat dihindari.

\section{i. Pemberian imunisasi}

Program Imunisasi merupakan salah satu upaya untuk melindungi anak terhadap penyakit tertentu. Maka sangat penting anak mendapatkan Imunisasi yang lengkap agar anak terhindar dari segala macam penyakit. Dalam hasil wawancara dengan pihak terkait di TK Alam Pelopor Rancaekek ini tidak ada program pemberian Imunisai namun pihak sekolah tetap mengarahkan untuk anak mendapatkan imunisasi dengan memberi rujukan dari sekolah untuk melakukan imunisasi di daerahnya masing-masing. Menurut Triana (2016), Setiap bayi wajib mendapatkan lima imunisasi dasar lengkap (LIL) yang terdiri dari: 1 dosis BCG, 3 dosis DPT, 4 dosis polio, 3 dosis hepatitis $\mathrm{B}$, dan 1 dosis campak. Pemberian imunisai pada anak perlu diberikan secara lengkap agar anak terhindar dari berbagai penyakit. $\mathrm{k}$. Pemeriksaan Kesehatan Mata, Telinga, Dan Mulut Anak

Program Layanan pemeriksaan mata, telinga, dan mulut pada anak di TK Alam Pelopor ini tidak diterapkan dikarenakan kurangnya kerjasama antara pihak sekolah dengan lembaga terkait sehingga program tersebut dapat terlaksana.

\section{Evaluasi}

Evaluasi pelaksanaan layanan kesehatan dan gizi dalam pelaksanaan PAUD Holistik Integratif di TK Alam Pelopor Rancaekek dilakukan oleh pihak yang bersangkutan dengan memanfaatkan data hasil instrumen pemantauan yang menggambarkan tingkat keberhasilan pelaksanaan layanan kesehatan dan gizi di TK Alam Pelopor Rancaekek.

Pelaksanaan evaluasi layanan kesehatan dan gizi dalam penyelenggaraan PAUD Holistik Integratif di TK Alam pelopor Rancaekek dengan melihat hasil pencapaian tingkat pelaksanaan dari program yang telah di buat selama satu semseter. Kepala sekolah telah membuat intrumen penilaian agar mempermudah dalam mengevaluasi hasil pelaksanaan program yang ada. Intrumen tersebut berisi tentang program, rincian kegiatan, hasil kegiatan, dan upaya penanggulangannya apabila terjadi masalah dalam pelaksanaan program layanan kesehatan dan gizi di TK Alam Pelopor.

Dari intsrumen yang telah dibuat oleh kepala sekolah TK Alam Pelopor Rancaekek guru mengevaluasi program layanan kesehatan dan gizi ini apakah sudah berjalan sebagai mana mestinya. Dan apabila masih ada program yang belum terlaksana guru melakukan penilaian terhadap kegiatan yang telah dibuat.

Evaluasi dari pihak luar dilaksanakan dengan pemantauan secara berkesinambungan agar pihak sekolah dapat berkonsultasi dan meminta bantuan apabila terjadi hambatan dalam pelaksanaan progam layanan kesehatan dan gizi di TK Alam Pelopor.

Pelaksanaan layanan kesehatan dan gizi di TK Alam Pelopor Rancaekek perlu diadakan evaluasi agar permasalahan yang terjadi dalam program tersebut dapat diperbaiki. Menurut hasil 
wawancara yang peneliti dapatkan evaluasi yang dilakukan dari pihak luar dalam menilai hasil kegiatan program yang sudah telaksana selama satu semester mengenai layanan kesehatan dan gizi yang ada di TK Alam Pelopor Rancaekek ini dilakukan dengan pihak komite sekolah. kegiatan ini dilaksanakan melalui rapat setiap semester untuk membicarakan dan menilai hasil kegiatan yang sudah teralaksana.

\section{SIMPULAN}

Simpulan yang di peroleh berdasarkan hasil penelitian dan pembahasan mengenai Penerapan layanan kesehatan dan gizi dalam penyelenggaraan PAUD HI TK Alam Pelopor Rancekekadalah sebgai berikut:

1. Perencaaan layanan kesehatan dan gizi dalam penyelenggaraam PAUD Holistik Integratif di TK Alam Pelopor Rancaekek dilaksanakan dengan mengacu pada pedoman pelaksanaan program layanan Holistik Integratif. layanan kesehatan dan gizi dilaksanakan oleh pengelola PAUD atau pengelola bersama para pendidik dan unsur terkait yang bertujuan untuk mengoptimalkan potensi dan peran instansi /lembaga terkait untuk memberikan dukungan dalam peningkatan mutu layanan PAUD. Bentuk kegiatan yang dilaksanakan dalam penyelenggaraan layanan kesehatan dan gizi di TK Alam Pelopor Rancaekek seperti pemeriksaan kesehatan secara rutin oleh petugas kesehatan setempat, lalu pemberian makanan tambahan bagi peserta didik dan pembiasaan hidup sehat di kalangan peserta didik. Evaluasi layanan kesehatan dan gizi dilihat hasil pencapaian dari kegiatan yang sudah dilaksanakan selama satu smseter dilakukan dengan membuat instrument penliaian. Intrumen tersebut berisi tentang program, rincian kegiatan, hasil kegiatan, dan upaya penanggulangannya apabila terjadi masalah dalam pelaksanaan program layanan kesehatan dan gizi di TK Alam Pelopor.

2. Pelaksanaan layanan kesehatan dan gizi di TK Alam Pelopor Rancaekek yang dilakukan oleh pihak sekolah berupa penimbangan berat badan yang dicatat dalam KMS secara berkala setiap bulan, Pembiasaan makan makanan sehat dan seimbang atau pemberian makanan tambahan secara berkala (disesuaikan dengan kemampuan lembaga), Pembiasaan mencuci tangan, menjaga kebersihan diri dan lingkungan, Pengenalan makan gizi seimbang dengan melibatkan orang tua dalam menyiapkan bekal untuk anak seharihari, Memantau asupan makanan yang dibawa anak setiap harinya termasuk jajanan yang dikonsumsi anak selama ada di Satuan PAUD, sedangkan pelaksanaan layanan dalam bentuk kerja sama dengan pihak luar di TK Alam Pelopor Rancaekek berupa Memberi fasilitas kepada tenaga Medis seperti, Melakukan Deteksi Dini Tumbuh Kembang (DDTK)/ Stimulasi Deteksi Intervensi Dini Tumbuh Kembang (SDIDTK), Perbaikan gizi, seperti pemberian vitamin A, Pemberian imunisasi, Pemeriksaan kesehatan mata, telinga, dan mulut anak.

Evaluasi layanan kesehatan dan gizi di TK Alam Pelopor Rancaekek mengacu pada instrument yang dibuat kepala sekolah untuk memudahkan penilaian dan capaian kegiatan dala satu semester, didalamnya berisi program kegiatan yang akan dilaksanakan, rincian kegiatan yan harus dicapai , hasil kegiatan yang sudah dicapai dan upaya penaggulangan apabila terjadi permasalahan dari program yang dibuat oleh pihak sekolah. 
DAFTAR RUJUKAN

Alfiana, R. (2016). Partisipasi
Masyarakat dalam
Pengembangan Layanan Anak
Usia Dini Holistik Integratif di
Pos PAUD Pelangi Kelurahan
Pedalangan Kecamatan
Banyumanik Semarang. (Doctoral
dissertation, Universitas Negeri
Semarang).

Ariani, A. (2017). Ilmu Gizi. Yogyakarta: Nuha Medika.

Astuti, A. (2016). Pelaksanaan Perilaku Sehat Pada Anak Usia Dini Di PAUD Purwomukti Desa Batur Kecamatan Getasan: Jurnal Scholaria, 6, 264-272.

Bappenas. (2012). Studi Kebijakan: Pengembangan Anak Usia Dini yang Holistik dan Terintegrasi. Jakarta: Bappenas.

Braun, Crakle. (2006). Using Thematic Analysis In Pshycology. Qualitative Research in pshycology, 3(2), 1-41.

Davidson, S., dkk. (2018). Densitas Gizi dan Morbiditas serta Hubungannya dengan Status Gizi Anak Usia Prasekolah Pedesaan: JURNAL MKMI, 14, 251-259.

Direktorat Pembinaan Pendidikan Anak Usia Dini. (2015). Petunjuk Teknis Penyelenggaraan Paud Holistik Integratif Di Satuan Paud. Jakarta.

Direktorat Jenderal Pendidikan Anak Usia Dini, Kemendiknas. (2011). Petunjuk Teknis Penyelenggaraan POS PAUD. Jakarta: Kemendiknas.

Fazrin, dkk. (2018). Pendidikan Kesehatan Deteksi Dini Tumbuh Kembang Pada Anak Di Tk Lab
School UNPGRI Kediri: Journal Of Community Engagement In Helath, 1(2), 6-14.

Julianti, dkk. (2018). Pelaksanaan Perilaku Hidup Bersih Dan Sehat (PHBS) Di Lingkungan Sekolah : Jurnal Ilmiah Potensia. 3(1), 1117.

Moleong, L. J. (2010). Metodologi Penelitian Kualitatif. Bandung: Remaja Rosda Karya.

Murage, E.W, Crispin, N., Katherine R., \& Peninah,M. (2012). Vitamin A supplementation and stunting levels among two year olds in Kenya: Evidence from the 200809 Kenya demographic and health survey. International Journal of Child Health and Nutrition, 1, 135- 147.

Nufus, H. (2016). Peranan Pendidikan Anak Usia Dini (PAUD) Dalam Membina Tumbuh Kembang Anak Di Kota Ambon: Jurnal AlIltizam, 1(1), 87-1.02.

Park, H. S. \& Kim, K. (2011). Parental involvement and students cognitive outcomes in korea: Focusing on private tutoring. Sociology of Education, 84 (1), 322.

Peraturan Menteri Kesehatan Republik Indonesia Nomor 66 Tahun 2014 Tentan Pemantauan Pertumbuhan, Perkembangan dan Gangguan Tumbuh Kembang anak.

Prima, Eni, dkk. (2017). Booklet Layanan kesehatan, Gizi dan Perawatan. Direktorat Pembinaan Pendidikan Anak Usia Dini, Direktorat Pendidikan Anak Usia Dini dan Pendidikan Masyarakat Kementerian Pendidikan dan Kebudayaan. 
Ranti, A. L., \& Santoso. S. (2004). Kesehatan dan Gizi. Jakarta: Departemen Pendidikan Nasional.

Triana, V. (2016). Faktor Yang Berhubungan Dengan Pemberian Imunisasi Dasar Lengkap Pada Bayi Tahun 2015. Jurnal kesehatan masyarakat Andalas, 10(2), 123-135.

Triwahyuni, Y, dkk. (2016). Penguasaan Pengetahuan Gizi calon Guru PAUD Sebagai Hasil Belajar Kesehatan Dan Gizi II Di PGPAUD UPI: Media Pendidikan Gizi dan Kuliner, 5(1), 78-98.

Usnawati, dkk. (2016). Jurnal Pemberian Layanan Pembinaan PAUD Untuk Mencapai Target SDIDTK Bagi Anak Balita, 7(3), 131-135.
Wijaya, A. M. (2010). Artikel Pengembangan Anak Usia Dini (PAUD) Holistik Integratif: Info Dokter. Online. Diakses dari https://www.infodokterku.com/in dex.php/en/103-daftarisicontent/infokesehatan/kesehata n-anak/192-pengembangananakusiadini-paudholistikintegratif.

Yuniarto, J. 2014. Pengembangan Program Holistik Integratif Di Sekolah Integral Hidayatullah Yaa Bunayya Batang Kabupaten Batang: Indonesian Journal of Early Childhood Education Studies, 3(1), 41-48.

Yin, R. K. (2013). Case Study Researce. California: Sage Publicaton. 